\section{THE QUARTERLY FOURNAL OF MICROSCOPICAL SCIENCE}

T'HE January number of this well-known scientific periodical appears in so new a form as to call for special notice. Under the editorship of Prof. R. Lankester it has long since attained a very high standpoint among the high-class journals of Europe, but it wanted a little in its general get-up to bring it to the very highest level of these, in such details as size, paper, and illustrations. No doubt such details are not to be taken for more than they are worth, and of late years it will be conceded by all those whose opinion is worth having that the value of the contents of the quarterly numbers of the journal left it in a gre it measure independent of mere typographical superfluities. Still it is very pleasant to find tlis eighty.ninth number of the New Series so splendidly got up-its paper and type are such as we might expect to find associated with some special monograph ; while the increased size (royal oztavo) enables the illustrati ns to be given on a scale quite up to anything we have been accustomed to in the very first of the German and French journals. Let us hope that the enterprise of both Editor and Publisher will meet with sufficient reward to enable them to continue to show what can be done in the way of a scientific journal in these countries.

That the contents are worthy of such a shrine is beyond dispute. Never has Prof. Lankester issued a more important number of his journal, as a mere enumeration of the contents as follows will show. Dr. E. Klein, On the relation of Pathogenic to Septic Bacteria, as illustrated by Anthrax cultivations. This paper relates to a most serious question : it is a model of fair and judicious criticism of the lab surs of others, and of skill in experimental details. Our space forbids an allu.ion to its conclusions ; but every medical man of any culture should read and re-read this memoir. Somewhere Claude Bernard has said,"Nowadays every medical man think; himself a physiologist." Such would profit by a perusal of this paper if they are able to understand its full significance.-E. B. Poulton, M.A., On the tongue of Perameles nasuta, with some suggestions a; to the origin of tastebulbs (Plate I).-Dr. L. Elsberg, Plant-cells and living matter. -F. O. B)wer, M.A., Plasmolysis and its bearing upon the relations of cell-wall and protoplasm (Plate 8).-Prof. A. P. Thomas, The life-history of the Liver Fluke (Fasciola hepatica), (Plates 2 and 3 ); a most elaborate, complete, and beautifully illustrated monograph.-W. F. R. Weldon, B.A., Note on the early development of Lacerta muralis (Plates 4.6).- R. V. Willemoes-Suhm (the late), On a crustaceous larva, at one time supposed to be the larva of Iimulus (Plate 7).-A. G. Bourne, B.Sc., On Haplobranchus, a new genus of Capitobranchiate annelids (Plate 9).-E. Ray Lankester, M.A., and A. G. Bourne, B.Sc., The minute structure of the lateral and the central eyes of Scorpio and of Limulu; (Plates I0-I2). The authors find, in the essential agreement of the central eyes of Limulus with those of Scorpions, another important detail which confirms the opinion of Prof. Lankester, that the Scorpions and King Crabs are closely-allied represeatatives of one class, the Arachnida.

\section{UNIVERSITY AND EDUCATIUNAL INTELLIGENCE}

OXFORD.-Dr. E. B. Tylor's first lecture on Anthropology will take place on Thursday, February 15, at $2.30 \mathrm{p} .1$., at the large lecture room at the University Museum, not on Wednesday, the I4th, as previously announced. The second lecture will be given at the same hour and place on Wednesday, the 2 Ist.

The voting for "elected members" of the new Boards of Faculties took place last Saturdav. The electors were the Members of Convocation, authorised by the Colleges to teach in the subjects of the various faculties. Mathematics and Natural Science are included in one faculty - that of Natural Science. As there are more college lecturers in Mathematics than in Natural Science, it was resolved at a preliminary meeting of the electors to choose five mathematicians and five teachers of Natural Science to occupy the ten places which were to be filled up. Ten names were then agreed upon, but at the formal meeting another mathematician and another scientist were proposed so that it became necessary to vote. The ten names before agreed upon were those chosen, the mathematician naturally heading the list. They are Messrs. IV. Esson, F.R.S. Merton, C. J. Faulkner, University,. C. Leudesdorf, Pem- broke, E. B. Elliott, Queen's, and J. W. Rusiell, Balliol, as representatives of mathematics; Messrs. R. E. Baynes, Christ Church, as a representative of Physics; Messrs. J. Watts, Merton, and A. G. Vernon Harcourt, F.R.S., Christ Church, as representatives of Chemistry; and Messrs. E. B. Poulton, Keble, and W. H. Jackson, New, as representatives of Biology. The Professors of Mathematics and Natural Science are ex officio members of the Board.

The Examiners for the Radcliffe Travelling Fellowship give notice that the examination will eommence at the Museum on February 13 .

The Examiners for the Burdett-Coutts Geological Scholarship give notice that the examination will commence on February I2. The serious illness of Prof. Henry J. S. Smith is causing much anxiety in the University.

CAMBRIDGE.-The syndicate appointed to frame regulations on the subject of the degree of Doctor in Science or Letters report that they think it important that precautions should be taken to secure that whenever a degree in Science or Letters is granted, the provisions of the statute requiring that the candidate shall have given proof of distinction by some original con. tribution to the advancement of science or learning have been bona fide complied with; but they think it undesirable to require from candidates any additional examination or special act or exercise. Considering that it is desirable to encourage the more distinguished graduates to turn their thoughts towards original work at a comparatively early age, and that it is not uncommon for able men to be elected Fellows of the Royal Society at the age of thirty or thereabouts, the Syndicate are of opinion that five years will be a sufficient interval between the degress of M.A. and D.S. or D.L. The Syndicate think that it is to be wished that some of the older graduates in Arts should proceed to their new degrees. They think that the probability of this would be increased if the seniority of all those who so proceed within a limited time were reserved to them. The Syndicate have carefully considered the difficulty which may arise from the ambiguity of the term "Science." They are of opinion that no regulations can be laid down drawing a clear line between claims for a degree in Science and claims for a degree in Letters.

The Syndicate have drawn up a code of regulations to the effect of the above. The fee to be payable for the degree of either Doctor of Science or Letters to be $20 l$.

Candidates' application; are to be sent to the Chairman of the Special Board of Studies with which their original contribution is most closely connected, specifying the printed contribution or contributions for which the degree is sought. The application is to be considered by a committee, and the contributions reported on by at least two persons, who. may be members of the committee or not. If the Special B sard report in favour of the candidate, the General Board of Studies is to have a voice in the matter, and if they approve, the Vice-Chancellor is to publish the name as approved.

The following are nominated Electors to the Professorships named :-

Chemistry.--Professors A. W. Williamson, Lord Rayleigh, Dewar, Frankland; Doctors Phear (Emmanuel College), and Ferrers (Caius), Prof. Fuller (of Aberdeen), and Mr. Coutts Trotter.

Jacksonian of Natural Philosophy.--Professors A. W. Williamson, G. G. Stokes, G. D. Liveing, Dr. Hugo Müller, F.R.S., Dr. M. Foster, Mr. P. T. Main, Prof, Fuller (Aber. deen), and Mr. Coutts Trotter.

Cavendish of Experimental Physics.-Sir W. R. Grove, Prof. G. G. Stokes, G. H. Darwin, Sir W. Thomson, R. B. Clifton, G. D. Liveing, James Stuart, and Mr. W. D. Niven.

The Smith's Mathematical Prizes are awarded to Messrs. Welsh, Jesus College (I), and Turner, Trinity College (2).

The Balfour Fund now amounts to about $4130 l$., in addition to the $4000 l$. contributed by his relatives and by Dr. Foster.

DURING last year there entered at the University of Upsala 330 students. In 1881 , the number was 312 ; in 1880,263 ; in I 879,259 ; in 1878,243 .

\section{SCIENTIFIC SERIALS}

Fournal de Physique, January, 1883.-On the metallic gratings of Mr. Rowland, by M. Mascart.-Résumé of experiments mide at the Exhibition of Electricity, on magneto- and dynamo- 